\title{
Behaviour of captive Ostrich chicks from 10 days to 5 months of age
}

\author{
Marina Freire Amado ${ }^{1}$, Diego Batista Xavier ${ }^{1}$, Vanner Boere $^{1}$, Carla Torres-Pereira ${ }^{2}$, \\ Concepta McManus ${ }^{1}$, Francisco Ernesto Moreno Bernal ${ }^{1}$
}

\footnotetext{
${ }^{1}$ Faculdade de Agronomia e Medicina Veterinária-Universidade de Brasília, Caixa Postal 04508, 70910-970, Brasília, DF, Brazil .

2 Centre for Animal Welfare and Anthrozoology-Veterinary Medicine-University of Cambridge, Madingley Road, Cambridge, CB3 OES, UK.
}

ABSTRACT - The behaviour of ostrich chicks bred in captivity was studied by using groups with 30 birds in five age groups: from 10 to 40 days of age; from 41 to 60 days of age; from 61 to 90 days of age; from 91 to 120 days of age and from 121 to 150 days of age. Six birds at each age were ringed around one of their feet and observed for four consecutive days for eight hours daily in three periods (in the morning, at noon and in the afternoon), following the "one-zero" method for sampling. The order for observation of behaviour of the six selected birds was performed randomly at every thirty minutes, totalling 16 periods or 80 minutes/bird/day. Fourteen types of behaviour were observed. There were differences among ages for behaviour like standing, walking, running, ingesting stones, ingesting feces, picking and attacking. Non-parametric-tests were used to analyse the behaviour according to age of the bird and to the periods of the day. There was a statistical difference between in the morning and at noon periods on behaviours standing, walking, eating ration and in litophagia, which were observed more frequently at the first hours of the day. When periods of the morning and afternoon were compared, the birds' age had a significant effect on behaviour sand bathing. When the periods noon/afternoon were compared, the behaviours which presented significant differences were walking, running, drinking water, eating ration, litophagia, coprophagia, dancing, sand bathing, whose occurrence was the highest during dusk. It was observed that the behaviour of young ostriches diverge according to the age and to day period.

Key Words: agonistic behaviour, breeding, ethogram, social behaviour, Struthio camelus, use of time

\section{Introduction}

Studies on behaviour are important for evaluation of the welfare of animals such as ostriches. Ostriches have not been selectively bred with the objective of minimising the effect of the stress experienced on farms.

The African ostrich is a social species, therefore it thrives better in groups (Bolwig, 1973). Thus, providing conditions where the animals can express their normal behaviours is one of the basic requirements of good welfare. According to Newberry et al. (2007), in the wild, pecking is a natural behaviour that leads to the establishment of a pecking order in the group. The chicken family groups are composed of one male, which holds a harem and the chicks. These authors observed that normal pecking behaviour in chickens can become pathological due to inadequate management, often leading to cannibalism.

Management strategies, such as grouping chicks for similar weights, may prevent unequal food intake between the larger and the smaller ostriches, which improves welfare conditions (Broom, 1986; Burger \& Gochfeld, 1988; Lambert et al., 1995; Tuckwell, 1997; Souza, 2004; Fraser \& Broom, 2007).
Adequate balanced feeding is essential to achieve good welfare as well as meat and egg production of ostriches (McKeegan \& Deeming, 1997). However, nutritional adequacy is not sufficient to prevent the occurrence of abnormal behaviours which are an indicator of poor welfare (Deeming, 1998).

It is well known that environmental stress leads to immunosuppression in many animal species (Broom \& Johnson, 2000). Stress affects learning abilities in most vertebrates, which is particularly relevant in ostrich chicks that often mimic food selection behaviour of their parents (Carrer, 2004).

Wild chicks eat faeces of their parents, which contributes to a microbial colonisation of the digestive tract facilitating digestion of the consumed food. In commercial ostrich production, the chicks do not have access to parental faeces but will feed on faeces from other chicks of the same age kept in the same pen (Carrer et al., 2005).

Chicken groups are characterised by hierarchies which start to be expressed at early stages of development (Croney et al., 2007). However, studies on ostrich chick behaviour are rare and few data are available. It is well known, from research in poultry production, that a disregard for pecking 
order may have negative implications for the welfare of birds. An understanding of the factors affecting pecking orders in ostriches should be used to improve production as observed for other bird species (McBride \& Foenander, 1962; Pagel \& Dawkins, 1997).

The objective of this study was to evaluate the behaviour of farm-hatched ostriches in captivity from ten days to five months of age, the critical time for the development and survival of the ostriches in these rearing systems.

\section{Material and Methods}

Five age groups of ostriches were compared during three periods in the day: morning, noon and afternoon on two farms near Brasilia, Brazilian mid-western region. Daily temperatures ranging from $22^{\circ} \mathrm{C}$ (early morning) to $35^{\circ} \mathrm{C}$ (mid-afternoon) were observed, with relative humidity ranging from $81 \%$ in the morning to $42 \%$ in mid-afternoon. No precipitation was recorded during the experimental period. The facilities were designed according to the Brazilian ostrich production standards (Souza, 2004) providing an outdoor fenced yard and a central shelter. The paddocks measured $20 \mathrm{~m} \times 20 \mathrm{~m}$ for each group of 30 birds, regardless of age until 5 months of age. After this, the paddock measured $20 \mathrm{~m} \times 30 \mathrm{~m}$ per group of 30 birds. The substratum of both covered and uncovered areas consisted of compacted soil with gravel and sand. Food (alfalfa grass, concentrate and water) were provided ad libitum three times a day early in the morning (6:00 a.m.), at noon and at 5:00 p.m. Birds at more than 60 days of age were moved to areas, providing them with a bigger space $\left(1,000 \mathrm{~m}^{2}\right)$.

To produce the ethogram, fourteen behaviours were observed: standing (S)- feet in one place with head raised; running (R) - locomotion with both feet off the ground at times, either parallel with the boundary of the enclosure or across the field; walking (W) - locomotion with one of the feet always in contact with the ground; drinking (D) ingestion of water from the bowl, this was counted on one bout if the head has raised for less than five seconds; feeding (F) - ingesting food; coprophagia (C) - eating faeces; lithophagia (L) - eating little stones; aggression (A) - hissing or kicking directed at other birds; dust-bathing (Db) - performed in the sitting position, usually in a consistently preferred location, the neck and tail are rubbed along the ground while the wings are flapped to generate a cloud of dust which coats the plumage; investigatory pecking $(\mathrm{P})$ - beak used for environmental exploration or social contact; sitting with the head high (SHh) - sitting with the head raised, eyes open or closed; sitting with the head low (SHl): sitting with the head lowered to preen, peck at ground or with the neck flat on the ground in front of the body; dancing (D) - jumping and skipping in a localised area and other pecking (OP) - pecking wood or fence (adapted from Csermely et al., 2007).

The observed birds were in five age groups, (I) from 10 to 40 days of age; (II) from 41 to 60 days of age; (III) from 61 to 90 days of age; (IV) from 91 to 120 days of age and (V) from 121 to 150 days of age. Each age group was consisted of 30 birds, but only six randomly selected chicks within each group selected daily were individually marked with different coloured Velcro rings and observed.

Observations on behavior were made in each age group, for four consecutive days, and at three different periods per day. Period 1 - from 8:00 a.m. to 11:00 p.m.; period 2 - from 11:00 a.m. to 2:00 p.m.; period 3 - from 2:00 p.m to 5:00 p.m.. Data was collected in March when days were cloudy and dry with $18^{\circ} \mathrm{C}$ minimum temperature and a maximum temperature of $28^{\circ} \mathrm{C}$ and relative humidity of $50 \%$.

Behaviour recording was done by using one-zero sampling as defined by Martin and Bateson (1986). Each individual was observed for five minutes at every half-hour, totalling 80 minutes a day $(16 \times 5$ minutes of observations for each bird). The lack of normality of distribution for some variables required the statistical analysis to be nonparametric. The mean frequency of occurrence per hour of observation was calculated for each group of birds. A Kruskal-Wallis test was used for differences in the expression of individual behaviours by age group. MannWhitney test was used to compare the behaviour of birds grouped by age and to compare behaviours among periods of the day. Spearman rank correlation was employed to evaluate the relationships among variables.

\section{Results and Discussion}

The behavioural repertoire in ostriches in the early months of life is especially directed towards exploration and knowledge of different aspects of the enclosure where they are kept in and also the establishment of interactions between birds. These interactions can set territorial areas and family groups in production systems.

The birds at 10 to 40 days og age spent little time standing when compared with those at 41 to 60 days of age $(\mathrm{z}=-3279 ; \mathrm{P}<0.001)$, from 91 to 120 days of age $(\mathrm{z}=-2760$; $\mathrm{P}<0.01)$, and from 121 to 150 days of age $(\mathrm{z}=-3098 ; \mathrm{P}<0.01)$ of age. Birds at 41 to 60 days of age stood more than birds at 61 to 90 days of age $(\mathrm{z}=-2442 ; \mathrm{P}<0.05)$, the latter group spending more time standing quiet than the older groups. From 10 to 40 days of age, birds walked more ( $4.66 \pm 0.19)$ than the other age groups studied (41 to 60 days of age 
$(\mathrm{z}=-2991 ; \mathrm{P}<0.01)$, from 61 to 90 days of age $(\mathrm{z}=-3194$; $\mathrm{P}<0.001)$, from 91 to 120 days of age $(\mathrm{z}=-2581 ; \mathrm{P}<0.01)$ and from 121 to 150 days of age $(\mathrm{z}=-3636 ; \mathrm{P}<0.001))$. Walking, running, consuming or attempting to consume objects found within the enclosure, such as stones or faeces, pecking a person, fighting for space or food trays can have all these objectives.

The birds in the first month of life walked and ran the most, whereas in the second month, birds stood still more (Table 1). This result was similar to that of Alvarenga (2006), who found that younger birds walked or ran more than when they were older. Csermely et al. (2006) observed the same in wild ostriches. They observed that ostriches in captivity present this behaviour as a function of frustration or limited environment. According to Kock (1996a, 1996b) the supply of a more natural environment seems to relieve the stress and frustration seen in ostrich chicks bred in captivity.

No statistical differences were observed between ages for drinking, feeding, dancing and dust bathing behaviours. Dancing was only observed in the first age group, and dust bathing was not observed in this group. Also, running was observed more in birds at 10 to 40 days of age $(0.88 \pm 0.15)$ than in birds at 41 to 60 days of age $(\mathrm{z}=-3049$; $\mathrm{P}<0.01)$, from 61 to 90 days of age $(\mathrm{z}=-3736 ; \mathrm{P}<0.001)$, from 91 to 120 days of age ( $\mathrm{z}=-4042 ; \mathrm{P}<0.001)$, from 121 to 150 days of age ( $\mathrm{z}=-4098 ; \mathrm{P}<0.001)$. The birds at 41 to 60 days of age ran more than older birds $(\mathrm{P}<0.05)$ (Table 1$)$.

Running or dancing may be related to play, to escape from situations involving risk or to the psychomotor development of the individual that performs the action. It is more prevalent in the early ages of life and decreases with time, a fact observed when comparing the second with third age periods. The act of running was generally observed when the birds reacted to some unknown type of noise or to the presence of the attendant for some kind of management, such as supply of food. Dances were observed at different studied ages, more often during morning than at other time. According to Stewart (1994), the dance can be seen in wild ostriches and also in animals reared in captivity. Deeming et al. (1996) observed dancing more often when the birds were in some type of shelter during the night and were released the following day. In the present study, the birds were in the shelter every day from 6:00 p.m. until 7:00 a.m. on the next day, so dancing was observed at 6:00 a.m. while still in the shelter.

Throughout the experiment, a low frequency of water consumption was observed in all studied age groups. The consumption of water could be related to the time of food consumption or environmental dryness (relative humidity during the experimental period reached $13 \%$ during the hottest hours of the day) and high environmental temperatures. Sambraus (1994a) reported that adult ostriches used only $1.1 \%$ of their time on activities related to water intake. Observations show that in the field, at times of strong heat, if the plastic drinking troughs are not covered, the water is too hot and ostriches avoid drinking the water, leading to dehydration (Souza, 2004). In this study, the water troughs were not covered. The consumption of water in free living ostriches is likely to be related to its availability. According to Carrer et al. (2005), the young ostriches have to learn how to drink water. The author says that colourful drinking troughs help attract birds and mirrors can be used at the bottom of drinking troughs to stimulate consumption. It is suggested that the low consumption by birds may be related to the small amount of plastic drinking troughs within the paddock (one per paddock), in addition to not being covered and the water not being changed periodically.

The consumption of stones was not observed in the group from ten to 40 days of age. In all paddocks, gravel and sand were available. Small stones were consumed as a daily routine by all other age groups (Table 1 ).

Table 1 - Mean frequencies of behaviours per ostrich at different ages reared in captivity ${ }^{1}$

\begin{tabular}{|c|c|c|c|c|c|}
\hline \multirow[t]{2}{*}{ Behaviour } & \multicolumn{5}{|c|}{ Age in days } \\
\hline & 10 to 40 & 41 to 60 & 61 to 90 & 91 to 120 & 121 to 150 \\
\hline Standing & $0.33 \pm 0.11 \mathrm{a}$ & $1.09 \pm 0.16 b$ & $0.55 \pm 0.11 \mathrm{a}$ & $0.8 \pm 0.14 \mathrm{ab}$ & $0.91 \pm 0.13 b$ \\
\hline Running & $0.88 \pm 0.15 a$ & $0.30 \pm 0.07 b$ & $0.15 \pm 0.06 \mathrm{c}$ & $0.10 \pm 0.04 \mathrm{c}$ & $0.08 \pm 0.03 c$ \\
\hline Lithophagia & $0.00 \pm 0.00 \mathrm{a}$ & $2.65 \pm 0.47 b$ & $2.40 \pm 0.17 b$ & $2.69 \pm 0.16 b$ & $2.29 \pm 0.20 b$ \\
\hline Coprophagia & $3.22 \pm 0.21 \mathrm{a}$ & $1.01 \pm 0.16 b$ & $1.02 \pm 0.09 b$ & $0.92 \pm 0.14 \mathrm{~b}$ & $0.81 \pm 0.12 b$ \\
\hline Drinking & $0.91 \pm 0.15$ & $1.13 \pm 0.18$ & $1.14 \pm 0.16$ & $0.88 \pm 0.08$ & $0.81 \pm 0.09$ \\
\hline Feeding & $3.31 \pm 0.20$ & $2.41 \pm 0.29$ & $2.94 \pm 0.29$ & $2.95 \pm 0.19$ & $0.81 \pm 0.09$ \\
\hline Dancing & $0.41 \pm 0.09$ & - & - & - & - \\
\hline Dust Bathing & - & $0.12 \pm 0.06$ & $0.11 \pm 0.04$ & $0.10 \pm 0.04$ & $0.06 \pm 0.03$ \\
\hline
\end{tabular}

1 The other behaviours were not noticed in the experimental birds during the experimental period.

a,b - Average values in line, followed by different letters, differ $(\mathrm{P}<0.05)$ by Kruskal-Wallis test. 
The conformation of the digestive system of birds and lack of structures for maceration of the food ingested explain why the birds need other types of tools for food maceration, such as the consumption of small stones for deposition in the gizzards and subsequent use in breaking down food. During the first days of life, care with the food ingested is fundamental. The particle size, as well as the quality and quantity of food should be smaller to prevent mortality, which is frequent due to poor management in breeding ostriches, rheas and other ratites. Consumption of stones started from 40 days of age after the birds were transferred to paddocks with soil and the presence of stones. This study showed that stone consumption was more frequent in the early hours of the day and late afternoon, maybe coinciding with food distribution or food intake. Milton \& Dean (1995) showed that ostrichs need to consume stones for their digestive process and to separate the nutrients from the feed more completely.

When assessing coprophagia, there was a higher frequency $(\mathrm{P}<0.001)$ seen in birds at 10 to 40 days of age than in older groups (Table 1 ). This behaviour observed in all stages of ostrich life, may be related to bacterial colonisation of the digestive system, mainly small intestine and large intestine-like caecal structures which allow for the fermentation of food components through bacterial action, which produces energy and protein of bacterial origin, as well as certain vitamins that can be used in maintenance. In the studied birds, a greater presentation of this behaviour, early in the morning and late in the evening was noted; these findings are in accordance with Souza (2004) and Carrer et al. (2005).

Pecking, in contrast, was not observed on birds at 10 to 40 days of age and occurred less on birds at 41 to 60 days of age than on birds at 61 to 90 days of age $(0.76 \pm 0.18$, $\mathrm{P}<0.01)$, at 90 to 120 days of age $(1.21 \pm 0.23, \mathrm{P}<0.001)$ and at 120 to 150 days of age $(0.63 \pm 0.16, P<0.01)$. Pecking, including pecking the food tray and the wire mesh of the fence, was present in all evaluated ages, being more frequent at 10 to 40 days of age. This behaviour was greater $(\mathrm{P}<0.001)$ in birds at 10 to 40 day of age when compared with older groups.

Differences in behaviour with age may be affected by the method for provision of food, the duration of food supply, the quantity and quality, the number of animals within the space, the space per bird at the food tray and the lack of incentives to show this behaviour. Birds at the fourth month of life pecked more than birds at the first month of age and were more aggressive. Alvarenga (2006), working with birds aged between 15 days to two months of age, showed that the aggressiveness of ostriches was the greatest in the first few days of life.

The ostriches (Table 2) stood still more in the morning than in the middle of the day. The birds also walked less in the middle of the day. They ran and drank more in the afternoon that at noon. The lowest frequency of eating and lithophagia were found at noon. Coprophagia and dancing were less observed in the middle of the day than in the afternoon. Dust-bath was observed mostly in the afternoon $(\mathrm{P}<0.05)$. High temperatures of approximately $35^{\circ} \mathrm{C}$ from 11:00 to 3:00 p.m. during experimental period may have caused a reduction in bird activity during this period.

The birds were observed drinking water and feeding with lower frequency in the middle of the day than to the other periods. Both drinking and feeding were different to period 3. According to Souza (2004), ostriches in captivity and in hot weather conditions drink water at dawn and at dusk.

During the trial period, there was a higher consumption of feed in the early hours of the day and during the afternoon, which coincides with the hours of lower environmental temperature, as well as the time when food is distributed. Nevertheless, higher temperatures from 11:00 a.m. to 3:00 p.m. may have led to a decrease in the food consumption to avoid caloric enhancement resulting from the digestion process.

Sambraus (1994a) and Deeming (1998) also found higher consumption of food during the morning when the food was

Table 2 - Mean values ( \pm SD) of behaviour in captive ostriches from 10 days to 5 months of age in relation to the day period

\begin{tabular}{lccc}
\hline Behaviour & & \multicolumn{3}{c}{ Time period on the day } \\
\cline { 2 - 4 } & From 8:00 a.m. to 11:00 a.m. & From 11:00 a.m. to 2:00 p.m. & From 2:00 p.m. to 5:00 p.m. \\
\hline Standing & $0.99 \pm 0.14 \mathrm{a}$ & $0.51 \pm 0.07 \mathrm{~b}$ & $0.71 \pm 0.10 \mathrm{ab}$ \\
Walking & $4.17 \pm 0.16 \mathrm{a}$ & $3.09 \pm 0.14 \mathrm{~b}$ & $4.24 \pm 0.16 \mathrm{a}$ \\
Running & $0.32 \pm 0.10 \mathrm{ab}$ & $0.17 \pm 0.05 \mathrm{~b}$ & $0.42 \pm 0.07 \mathrm{a}$ \\
Drinking & $1.05 \pm 0.12 \mathrm{ab}$ & $0.77 \pm 0.07 \mathrm{~b}$ & $1.11 \pm 0.12 \mathrm{a}$ \\
Feeding & $3.44 \pm 0.17 \mathrm{a}$ & $1.97 \pm 0.13 \mathrm{~b}$ & $3.15 \pm 0.15 \mathrm{a}$ \\
Lithophagia & $2.27 \pm 0.34 \mathrm{a}$ & $1.56 \pm 0.16 \mathrm{~b}$ & $2.19 \pm 0.24 \mathrm{a}$ \\
Coprophagia & $1.54 \pm 0.23 \mathrm{ab}$ & $1.07 \pm 0.16 \mathrm{~b}$ & $1.58 \pm 0.20 \mathrm{a}$ \\
Dancing & $0.26 \pm 0.17 \mathrm{ab}$ & $0.30 \pm 0.07 \mathrm{~b}$ & $0.68 \pm 0.16 \mathrm{a}$ \\
Dust bathing & $0.00 \pm 0.00 \mathrm{~b}$ & $0.00 \pm 0.00 \mathrm{~b}$ & $0.30 \pm 0.05 \mathrm{a}$ \\
\hline
\end{tabular}

Average values in the same line, followed by different letters, differ $(\mathrm{P}<0.05)$ by Kruskal-Wallis test. 
supplied, and McKeegan \& Deeming (1997), who observed pairs of adult ostriches in captivity, reported a peak in the consumption of feed in the morning for both sexes. In the present study, temperature and food offer were confounded, therefore it was not possible to separate their effects.

On the other hand, it was reported by Sauer \& Sauer (1966) that ostriches in natural environments spend most of the time walking and feeding during the day, including grazing and seeking other kinds of food. This probably relates exploratory behaviour with the aim of achieving the daily nutritional requirements.

In this study, the ostriches at the hours close to noon, showed a calm behaviour. They spent more time standing in the early hours of the day. Deeming (1998) found no diurnal variation in the frequency of this behaviour during the winter in captive ostriches. Similar results were found by Ross \& Deeming (1998), who studied the behaviour of ostriches during the summer. In this study, the birds were moving more in the early hours of the day and at the end of the afternoon, which is in accordance with the results found by McKeegan \& Deeming (1997), who reported greater expression of this behaviour in the morning and afternoon in captive male ostriches.

Dust bathing was observed more frequently at late afternoon; however, this behaviour was not often noticed, and depended on the presence of sand or soil in the paddocks. McKeegan \& Deeming (1997) stated that this behaviour breeding represented a small portion of the time available during summer in Great Britain. Sambraus (1994b) reported that the incidence of this ostrich behaviour was very low in the morning and increased in the afternoon with peaks at sunset.

\section{Conclusions}

The ostriches studied show behaviour that changed during the day and with age. However, it is not possible to define precisely what is normal or not, as the conditions may not be ideal for the ostrich welfare. More studies should be carried out to determine the real needs of this bird species under production system conditions in different places in the world. It was not found pecking among young ostriches or other behaviour that suggested that there is dominance or feeding order for these groups of birds.

\section{Acknowledgments}

To CAPES for granting a scholarship for the last author.

\section{References}

ALVARENGA, A.B.B. Ontogenia comportamental, estilos de enfrentamento e crescimento em avestruzes (Struthio camelus). 2006. 83f. Dissertação (Mestrado em Produção Animal) - Faculdade de Agronomia e Medicina Veterinária/ Universidade de Brasília, Brasília.

BOLWIG, N. Agonistic and sexual behaviour of the african ostrich (Struthio camelus). The Condor, v.75, n.1, p.100-105, 1973.

BROOM, D.M. Indicators of poor welfare. British Veterinary Journal, v.142, n.6, p.524-526, 1986.

BROOM, D.M.; JOHNSON, K.G. Stress and animal welfare. London: Chapman and Hall, 2000. 211p.

BURGER, J.; GOCHFELD, M. Effect of group size and sex on vigilance in ostriches (Struthio camelus): antipredator strategy or mate competition? Ostrich, v.59, n.1, p.14-20, 1988.

CARRER, C.C. A criação do avestruz: Guia completo de A a Z. Pirassununga: Grupo Ostrich do Brasil, 2004. 255p.

CARRER, C.C.; CARRER, C.R.O.; ELMOR, R.A. et al. Estrutiocultura: planejamento, manejo e mercado. In: ZOOTEC'2005, Campo Grande. Anais... Campo Grande, 2005. p.33.

CRONEY, C.C.; PRICE-KELLY, N.; MELLER, C.L. A note on social dominance and learning ability in the domestic chicken Gallus gallus. Applied Animal Behaviour Science, v.105, n.1-3, p.254-258, 2006.

CSERMELY, D.; GAIBANI, G.; DARDANI, E. Year-round behavioural sequences in captive ostrich Struthio camelus domesticus pairs. Applied Animal Behaviour Science, v.103, n.1-2, p.156-166, 2007.

DEEMING, D.C.; BUBIER, N.E. Behaviour in natural and captive environments. In: DEEMING, D.C. (Ed.) The ostrich: biology, production and health. Wallingford: CAB International, 1999. p.83-104.

DEEMING, D.C. A note on effects of gender and time of day on the winter time-activity budget of adult ostriches (Struthio camelus) in a farming environment. Applied Animal Behaviour Science, v.59, n.4, p.363-371, 1998.

DEEMING, D.C.; BUBIER, N.E.; PAXTON, C.G.M. et al. A review of recent work on the behaviour of young ostrich chicks with respect to feeding. In: RATITE CONFERENCE, 1996, Oxfordshire. Proceedings... Oxfordshire, 1996. p.20-21.

FRASER, S.F.; BROOM, D.M. Farm animal behaviour and welfare. New York: Cab International. 2007.437p.

KOCK, J.A. Artificial rearing of chickens. In: DEEMING, D.C. (Ed.) Guidelines for successful ostrich farming. Oudtshoorn: Little Karoo Agricultural Development Centre, 1996b. p.18-23.

KOCK, J.A. Natural rearing of chickens up to three months of age. In: Guidelines for successful ostrich farming. Oudtshoorn: Little Karoo Agricultural Development Centre, 1996a. p.24-27.

LAMBERT, M.S.; DEEMING, D.C.; SIBLY, R.M. et al. The relationship between pecking behaviour and growth rate of ostrich (Struthio camelus) chicks in captivity. Applied Animal Behaviour Science, v.46, n.1-2, p.93-101, 1995.

MARTIN, P.; BATESON, P. Measuring behaviour: an introductory guide. Cambridge: Cambridge University Press, 1986. 199p.

McBRIDE, G.; FOENANDER, F. Territorial behaviour in flocks of domestic fowls. Nature, v.194, p.102, 1962.

McKEEGAN D.E.F.; DEEMING, D.C. Effects of gender and group size on the time-activity budgets of adult breeding ostriches (Struthio camelus) in a farming environment. Applied Animal Behaviour Science, v.51, n.1-2, p.159-177, 1997.

NEWBERRY, R.C.; KEELING, L.J.; ESTEVEZ, I. et al. Behaviour when young as a predictor of severe feather pecking in adult laying hens: the redirected foraging hypothesis revisited. Applied Animal Behaviour Science, v.107, n.3-4, p.262-274, 2007. 
PAGEL, M.; DAWKINS, M.S. Peck orders and group size in laying hens: 'futures contracts' for non-aggression. Behavioural Processes, v.40, n.1, p.13-35, 1997.

ROSS, E.J.; DEEMING, D.C. Feeding and vigilance behaviour of adult ostriches breeding in a farmed environment in Britain. British Poultry Science, v.39, n.2, p.173-177, 1998.

SAMBRAUS, H.H. Comfort behavior of the African ostrich (Struthio camelus). Deutsche Tierarztliche Wochenschrift, v.101, n.1, p.307-308, 1994b.

SAMBRAUS, H.H. The circadian rhythm in the behaviour of ostriches (Struthio camelus) kept in pens. Deutsche Tierarztliche Wochenschrift, v.107, n.10, p.339-341, 1994a.
SAMSON, J. Behavioral problems of farmed ostriches in Canada. Canadian Veterinary Journal, v.37, n.7, p.412-414, 1996. SAUER, E.G.F.; SAUER, E.M. The behaviour and ecology of the South African ostrich. Living Bird, Supplement 5, p.45-75, 1966.

SOUZA, J.S. Criação de avestruz. Viçosa, MG: Aprenda Fácil, 2004. 211p.

STEWART, J.S. Ostrich behaviour and behavioural problems. In: ANNUAL MEETING OF THE ASSOCIATION OF AVIAN VETERINARIAnS, 1994, Reno. Proceedings... Reno, 1994. p.103-109.

TUCKWELL, C.D. The ostrich book. Adelaide: Rural Industry Developments PTY LTDA, 1997. 96p. 